\title{
POTENSI BAKTERI ENDOFIT DALAM MENEKAN PENYAKIT LAYU STEWART (PANTOEA STEWARTII SUBSP. STEWARTII) PADA TANAMAN JAGUNG
}

\author{
Haliatur Rahma ${ }^{1}$, Aprizal Zainal ${ }^{1}$, Memen Surahman' ${ }^{2}$, Meity S.Sinaga ${ }^{3}$, \& Giyanto $^{3}$ \\ ${ }^{1}$ Program Studi Agroekoteknologi Faperta Universitas Andalas, \\ Kampus Unand Limau Manis Padang 25000 \\ ${ }^{2}$ Departemen Agronomi dan Hortikultura Fakultas Pertanian IPB \\ ${ }^{3}$ Departemen Proteksi Tanaman Fakultas Pertanian IPB \\ Jl. Kamper Kampus IPB Darmaga Bogor 16680 \\ E-mail: haliatur_rahma@yahoo.com
}

\begin{abstract}
Potential of endophytic bacteria to control stewart wilt disease (Pantoea stewartii subsp. stewartii) in maize. The purpose of this study was to explore endophytic bacteria from seedling, maize roots and grass roots as well as to test the ability of endophytic bacteria which could potentially suppress stewart wilt disease development in maize. Characterization of endophytic bacteria as biocontrol agents including: do not induce HR on tobacco, synthesize IAA, dissolve phosphate, produce siderophores, and antibiotic to Pantoea stewartii subsp. stewartii (Pnss). The results of research shoed 17 isolates of endophytic bacteria potentially as candidate biocontrol agents. Nine isolates were able to produce IAA, siderofores and phosphatase; two isolates produce IAA and phosphatase; six isolates produce IAA. Six isolates ie: AR1, AJ34, AJ15, AJ19, and AJ14 AN6, can increase maize plant resistance and suppress stewart wilt disease severity with a range of 48.95-55.60\%.
\end{abstract}

Key words: auxin, induced systemic resistance, salicylic acid, siderophore

\section{ABSTRAK}

Potensi bakteri endofit dalam menekan penyakit layu stewart (Pantoea stewartii subsp. stewartii) pada tanaman jagung. Penelitian ini bertujuan untuk eksplorasi dan identifikasi bakteri endofit dari jaringan akar dan benih jagung serta akar rumput alang-alang yang tumbuh di lahan jagung, kemudian dilanjutkan dengan menguji efektifitas bakteri endofit untuk mengendalikan penyakit layu stewart. Karakterisasi bakteri endofit sebagai agens hayati meliputi: tidak menginduksi HR pada tembakau, mensintesis IAA, melarutkan fosfat, menghasilkan siderofor, dan antibiosis terhadap Pantoea stewartii subsp. stewartii (Pnss). Hasil penelitian diperoleh 17 isolat bakteri endofit dengan kriteria sebagai berikut: 9 isolat mampu mensintesis IAA, melarutkan fosfat, menghasilkan siderofor dan bersifat antibiosis; 2 isolat mampu mensintesis IAA dan melarutkan fosfat dan 6 isolat hanya mampu mensintesis IAA. Enam isolat endofit yaitu AR1, AJ34, AJ15, AJ19, AN6 dan AJ14, mampu meningkatkan ketahanan tanaman jagung dengan menekan keparahan penyakit layu stewart dengan kisaran 48,95-55,60\%.

Kata kunci: antibiosis, asam salisilat, auksin, siderofor

\section{PENDAHULUAN}

Penyakit layu stewart pada tanaman jagung disebabkan oleh bakteri Pantoea stewartii subsp. stewartii (Pnss), merupakan penyakit yang baru terdeteksi di Indonesia. Penyakit ini bersifat tular benih (seedborne pathogen) dan ditularkan oleh serangga (Chaetocnema pulicaria). Gejala penyakit ini pertama kali ditemukan di Sumatera Barat dengan kejadian penyakit $1-15 \%$. Gejala berupa klorosis pada permukaan daun, layu dan kerdil pada fase vegetatif sedangkan pada tanaman dewasa gejala berupa bercak hijau kekuningan pada permukaan daun yang disertai dengan matinya jaringan (klorosis) (Rahma \&
Armansyah, 2008). Survei di sentra produksi jagung di Jawa Barat menunjukkan gejala penyakit yang mirip dengan di Sumatera Barat, dengan kejadian penyakit berkisar 26,7-52,41\% (Rahma, 2013).

Penyakit layu stewart pada jagung baru terdeteksi di Indonesia, oleh karena itu perlu diupayakan teknik pengendalian yang ditujukan pada benih sehingga penyakit ini tidak menyebabkan kerugian yang lebih besar di kemudian hari. Untuk mencegah epidemi penyakit layu stewart di lapangan, selain menggunakan varietas yang tahan, dapat dilakukan dengan menggunakan benih yang bebas patogen. Sejauh ini perlakuan benih untuk mengurangi inokulum Pnss di luar negeri masih menggunakan insektisida sintetis yang mengandung 
imidakloprit untuk pengendalian serangga vektor dan antibiotik untuk perlakuan benih. Untuk itu perlu diupayakan pengendalian alternatif untuk mengurangi penggunaan senyawa kimia yang berdampak negatif terhadap kesehatan manusia, kerusakan lingkungan serta ketidakseimbangan ekosistem. Perlakuan benih secara biologi menggunakan bakteri endofit dapat dijadikan sebagai alternatif pengganti bahan kimia sinstetis. Bakteri endofit merupakan bakteri yang hidup dalam jaringan tanaman tanpa menimbulkan kerusakan pada tanaman (Hallmann, 2001). Keberadaan bakteri endofit di dalam jaringan tanaman selain mendapatkan nutrisi untuk perkembangan dan pertumbuhannya ternyata juga memberi dampak terhadap perkembangan tanaman. Bakteri endofit mampu meningkatkan perkecambahan benih dan meningkatkan pertumbuhan tanaman (Chanway, 1997).

Penelitian ini bertujuan untuk eksplorasi dan identifikasi bakteri endofit serta menguji kemampuan bakteri endofit untuk mengendalikan penyakit layu stewart pada tanaman jagung.

\section{METODE PENELITIAN}

Tempat dan Waktu. Penelitian dilakukan di Laboratorium Bakteriologi Tumbuhan Departemen Proteksi Tanaman dan Rumah Kaca Cikabayan Institut Pertanian Bogor. Penelitian berlangsung mulai bulan Maret 2011 sampai dengan Agustus 2012.

\section{Isolasi Bakteri Endofit dari Akar dan Benih}

Jagung. Isolasi bakteri endofit dari akar jagung dilakukan menggunakan metode Zinniel et al. (2002). Sampel akar jagung dicuci dengan air mengalir, kemudian ditimbang sebanyak $1 \mathrm{~g}$. Sterilisasi permukaan akar dilakukan dengan menggunakan sodium hipoklorit ( $\mathrm{NaOCl} 2 \%)$ selama 60 detik. Akar kemudian dicuci 3 kali dengan akuades steril dan dikeringkan dengan kertas tissue steril. Isolasi bakteri endofit dari benih jagung dilakukan dengan metode Rijavec et al. (2007). Benih jagung disterilisasi permukaan dengan alkohol $70 \%$ selama 3 menit dan dilanjutkan dengan $\mathrm{NaOCl} 2 \%$ selama 3 menit, kemudian dibilas dengan akuades steril. Benih yang telah disterilisasi permukaan kemudian disusun pada kertas stensil yang sudah dilembabkan, dan digulung untuk menjaga kelembaban dan diinkubasi pada suhu ruang. Benih yang telah berkecambah dan akar jagung yang telah disterilisasi permukaan, dimaserasi menggunakan mortar steril, dan dibuat seri pengenceran sampai $10^{-4}$, dari masing-masing pengenceran diambil $100 \mu 1$ dan disebar pada media TSA (Tryptic Soy Agar) kemudian diinkubasi pada suhu ruang selama 5 hari.
Sebagai kontrol, air cucian benih yang terakhir diambil $100 \mu \mathrm{l}$ dan disebar pada media TSA. Apabila pada kontrol ditumbuhi oleh bakteri atau cendawan, maka percobaan dianggap gagal dan diulangi sampai pada kontrol tidak ada pertumbuhan mikroorganisme. Untuk membuktikan bahwa bakteri endofit yang diperoleh bukan golongan patogen tanaman, maka dilakukan uji reaksi hipersensitif (HR) pada daun tembakau.

\section{Karakterisasi Bakteri Endofit sebagai Agens Hayati terhadap Penyakit Layu Stewart}

Produksi Hormon Tumbuh IAA. Produksi hormon tumbuh IAA menggunakan prosedur yang dideskripsikan oleh Pattern \& Glick (2002). Isolat bakteri endofit ditumbuhkan dalam media Nutrien Broth $(25 \mathrm{ml})$ dengan ditambah $5 \mathrm{ml}$ larutan L-TRP $(0,5 \%)$ dan tanpa larutan L-TRP dan diseker $120 \mathrm{rpm}$, suhu $28^{\circ} \mathrm{C}$ selama 24 jam, kemudian di-centrifuge selama 10 menit. Satu ml supernatan dipindahkan dalam tabung reaksi dan ditambah $2 \mathrm{ml}$ reagent Salkowsky. Setelah 20-25 menit dibaca pada $535 \mathrm{~nm}$ pada spektrofotometer. Sebagai pembanding digunakan IAA murni dengan konsentrasi $0,5,10,15,20,25,30,35,40$, dan $4515 \mu \mathrm{g} / \mathrm{ml}$.

Uji Pelarut Fosfat. Uji pelarutan fosfat dilakukan dengan menggunakan metode standar yaitu menumbuhkan isolat bakteri endofit pada media Pikovskaya agar. Pengukuran yang dilakukan berupa rasio zona bening dengan membandingkan diameter zona bening dan diameter koloni setelah dinkubasi selama 2 minggu pada suhu ruang (Rao \& Sinha, 1962; Rao, 1994). Zona bening yang terdapat disekeliling koloni diamati dan diukur indeks pelarutan fosfatnya berdasarkan rumus:

Indeks Pelarut Fosfat $=\frac{\text { diameter zona bening }(\mathrm{mm})}{\text { diameter } \operatorname{koloni}(\mathrm{mm})}$

\section{Potensi Bakteri Endofit dalam Menekan Penyakit Layu Stewart}

Uji Kemampuan Antagonis Bakteri Endofit terhadap Pnss secara In Vitro. Pengujian dilakukan pada media TSA agar dengan metode Difusi Kertas Cakram-Agar (Madigan et al. 1997). Masing-masing isolat bakteri endofit dan Pnss dibiakkan pada media TSA selama 48 jam, kemudian dibiakkan dalam media TSB. Pengujian isolat bakteri endofit dilakukan dengan meletakkan 4 potongan kertas saring steril berdiameter $0,5 \mathrm{~cm}$ pada cawan Petri yang berisi media TSA dan $100 \mu \mathrm{l}$ suspensi isolat Pnss BGR28 (10 $\mathrm{CFU} / \mathrm{ml})$. Pada 
kertas saring kemudian ditetesi $10 \mu \mathrm{l}$ suspensi isolat bakteri endofit $\left(10^{8} \mathrm{CFU} / \mathrm{ml}\right)$, sebagai kontrol 1 kertas saring ditetesi dengan $10 \mu 1$ akuades steril (Sigee, 1993). Masing-masing isolat endofit diuji 4 kali dan peubah yang diamati adalah diameter zona hambatan di sekeliling kandidat bakteri endofit.

Uji Kemampuan Bakteri Endofit Menekan Infeksi Pnss In Planta. Penelitian ini menggunakan 17 isolat bakteri endofit hasil isolasi. Benih jagung rentan terhadap Pnss (varietas SD 3) (Rahma et al., 2013) direndam selama 12 jam pada kultur bakteri endofit dalam media Luria Bertani (populasi $\left.10^{8} \mathrm{cfu} / \mathrm{ml}\right)\left(\mathrm{OD}_{600}\right.$ $=0,3$ ), benih jagung juga direndam dengan air steril yang berfungsi sebagai kontrol. Media tanam berupa campuran tanah humus dan pupuk kandang (perbandingan 1:1 v/v) yang telah disterilkan. Setelah melalui proses perendaman, benih jagung dikeringanginkan dan ditanam. Setelah bibit jagung berumur 8 hari dilakukan inokulasi dengan Pnss BGR28. Penelitian dilakukan dengan menggunakan Rancangan Acak Kelompok satu faktor, dengan 3 kali ulangan. Peubah yang diamati dalam penelitian ini adalah: masa inkubasi dan keparahan penyakit layu stewart. Keparahan penyakit dihitung menggunakan rumus Townsend \& Hueberger (dalam Unterstenhofer, 1963) sebagai berikut:

$$
\mathrm{KpP}=\frac{\sum_{0}^{4}\left(\mathrm{n}_{\mathrm{i}} \times \mathrm{v}_{\mathrm{i}}\right)}{\mathrm{Z} \times \mathrm{N}}
$$

$\mathrm{KpP}=$ Keparahan penyakit

$\mathrm{n}_{\mathrm{i}} \quad=$ Jumlah tanaman yang terinfeksi pada setiap kategori

$\mathrm{v}_{\mathrm{i}} \quad=$ nilai numerik masing-masing kategori serangan; i : $0,1,2,3,4$

$\mathrm{Z}=$ Nilai numerik kategori serangan tertinggi (4)

$\mathrm{N} \quad=$ jumlah tanaman yang diamati

Data yang diperoleh dianalisis secara statistik dan jika terdapat pengaruh nyata dilakukan uji lanjut DNMRT pada taraf $5 \%$.

\section{HASIL DAN PEMBAHASAN}

Isolasi dan Seleksi Bakteri Endofit. Hasil isolasi bakteri endofit didapatkan 69 isolat yang terdiri atas 37 isolat dari akar tanaman jagung, 27 isolat dari kecambah benih jagung serta 5 isolat dari akar rumput yang tumbuh disekitar pertanaman jagung. Hanya 17 isolat bakteri endofit yang layak sebagai kandidat agens hayati, dengan kriteria tidak menginduksi HR pada tanaman tembakau. Kriteria ini menunjukkan bahwa isolat bakteri endofit yang diperoleh bukan kelompok bakteri patogen tanaman. Karakterisasi sifat bakteri endofit sebagai

Tabel 1. Karakterisasi sifat bakteri endofit sebagai pemacu pertumbuhan tanaman jagung

\begin{tabular}{clccc}
\hline Kode isolat & Asal Isolat & Sintesis IAA ${ }^{\mathrm{a}}$ ) & Indeks Pelarut Fosfat & Siderofor $^{\mathrm{b}}$ ) \\
\hline AJ8 & akar jagung & kuat & 4 & + \\
AJ12 & akar jagung & sedang & 16 & + \\
AJ14 & akar jagung & kuat & 20 & + \\
AJ15 & akar jagung & kuat & 12 & + \\
AJ19 & akar jagung & kuat & 12 & + \\
AJ22 & akar jagung & kuat & 4 & + \\
AJ34 & akar jagung & sedang & 12 & + \\
BS 5 & kecambah Bisi 2 & lemah & - & - \\
BS7 & kecambah Bisi 2 & lemah & 4 & - \\
SS9 & kecambah Hawai & lemah & - & - \\
BM 4 & kecambah Bima 5 & lemah & - & - \\
AN6 & kecambah Anoman & sedang & 12 & - \\
KB4 & kecambah SD 3 & lemah & - & - \\
DK1 & kecambah Dekalb & lemah & - & - \\
DK2 & kecambah Dekalb & lemah & - & + \\
AR 1 & akar rumput & kuat & 12 & + \\
AR2 & akar rumput & kuat & 16 & - \\
\hline
\end{tabular}

${ }^{\mathrm{a}}$ kuat $=\mathrm{n}>10 \mu \mathrm{gml}^{-1}$, sedang $=5 \mu \mathrm{gml}^{-1}<\mathrm{n} \leq 10 \mu \mathrm{gml}^{-1}$, lemah $=\mathrm{n} \leq 5 \mu \mathrm{gml}^{-1} ;{ }^{\mathrm{b}}(+)=$ menghasilkan siderofor,

$(-)=$ tidak menghasilkan siderofor 
agens hayati diantaranya adalah kemampuan dalam mensintesis IAA, melarutkan fosfat dan produksi siderofor (Tabel 1). Semua isolat endofit mampu mensintesis IAA mulai dari kategori lemah, sedang sampai kuat. Sebelas isolat endofit mampu melarutkan fosfat, sembilan isolat mampu menghasilkan siderofor.

Mekanisme yang terjadi akibat interaksi bakteri endofit dengan tanaman diantaranya adalah kemampuan bakteri meningkatkan pertumbuhan tanaman, hal ini dikaitkan dengan kemampuannya dalam menghasilkan hormon IAA. Hormon IAA merupakan sejenis auksin, terlibat dalam proses fisiologis dalam pertumbuhan tanaman seperti pemanjangan dan pembelahan sel, diferensiasi jaringan, dan inisiasi akar (Gravel et al., 2007). Hormon ini biasanya diproduksi oleh mikroba tanah, termasuk bakteri endofit (Kuklinsky-Sobral et al., 2004).

Kemampuan melarutkan fosfat merupakan salah satu mekanisme peningkatan pertumbuhan secara langsung oleh bakteri tanah kelompok PGPR. Tanah biasanya mengandung jumlah fosfat yang tinggi, tapi ketersediaan untuk tanaman terbatas dan juga tergantung pada pH tanah (Rodríguez \& Fraga, 1999). Hasil penelitian Kuklinsky-Sobral et al. (2004) menunjukkan bahwa dari 373 isolat endofit yang diisolasi dari tanaman kedelai, hanya $49 \%$ yang mampu melarutkan fosfat. Sebaliknya Long et al. (2008) melaporkan bahwa dari 77 isolat endofit yang diisolasi dari Solanum nigrum (leunca) hanya enam isolat yang mampu melarutkan fosfat anorganik.

Siderofor yang diproduksi oleh berbagai mikroorganisme yang bersimbiosis dengan akar tanaman dipengaruhi oleh kondisi lingkungan yang kekurangan $\mathrm{Fe}^{3+}$. Beberapa peneliti telah melaporkan tentang kemampuan bakteri endofit memproduksi siderofor. Barzanti et al. (2007) melaporkan bahwa 83\% dari endofit yang diisolasi dari Alyssum bertolonii Desv.
(Brassicaceae) menghasilkan siderofor. Sessitsch et al. (2004) menemukan bahwa 77\% dari 35 endofit yang diisolasi dari tanaman kentang memiliki siderofor.

\section{Pemanfaatan Bakteri Endofit untuk Mengendalikan Penyakit Layu Stewart pada Tanaman Jagung}

\section{Potensi Antagonis Isolat Bakteri Endofit terhadap}

Pnss In Vitro. Hasil pengujian antagonis diperoleh sembilan isolat endofit yang mampu menghambat pertumbuhan bakteri Pnss (Tabel 2). Terbentuknya zona bening di sekitar koloni bakteri endofit diduga bakteri ini menghasilkan senyawa antibiotik. Menurut Chen et al. (1995), kemampuan bakteri endofit menghambat pertumbuhan patogen terjadi melalui produksi senyawa antimikroba dan siderofor.

Velusamy et al. (2006) melaporkan bahwa Pseudomonas fluorescens mampu menghambat pertumbuhan penyakit penyebab hawar daun pada padi (Xanthomonas oryzae pv. oryzae) dengan menghasilkan antibiotik 2.4 diacetylphloroglucinol (DAPG). Awais et al. (2010) menambahkan bahwa bakteri Bacillus spp. menghasilkan antibiotik bacitracin, polymyxin, gramicidin, tyrocidin, subtilin dan bacilysin. Selain menghasilkan antibiotik, kemampuan menghambat pertumbuhan patogen oleh bakteri antagonis juga berkaitan dengan kemampuan bakteri ini menghasilkan asam sianida (HCN). Senyawa ini merupakan salah satu metabolit sekunder yang dihasilkan oleh bakteri Pseudomonas spp. dan bersifat antimikroba (Fuente et al., 2004).

Senyawa antibiotik yang dihasilkan oleh bakteri antagonis dapat menekan perkembangan bakteri patogen secara langsung bersifat sebagai bakterisida dan sebagai agens penginduksi (elicitor) ketahanan tanaman terhadap penyakit Lyon (2007). Menurut Whipps (2001),

Tabel 2. Kemampuan bakteri endofit menghambat pertumbuhan bakteri Pnss pada media TSA

\begin{tabular}{cccc}
\hline Isolat Endofit & Zona bening & Isolat Endofit & Zona bening \\
\hline AJ8+ & + & SS9 & - \\
AJ12 & + & BM4 & - \\
AJ14 & + & AN6 & + \\
AJ15 & ++ & AR1 & + \\
AJ19 & + & AR2 & - \\
AJ22 & - & KB4 & - \\
AJ34 & + & DK1 & + \\
BS5 & - & DK2 & \\
BS7 & - & & \\
\hline
\end{tabular}

$(-)=$ tidak ada zona bening, $(+)=0,1 \mathrm{~cm} \leq \mathrm{n} \leq-1 \mathrm{~cm} ;(++)=1 \mathrm{~cm}<\mathrm{n} \leq 1,5 \mathrm{~cm} ;(+++): \mathrm{n}>1,5 \mathrm{~cm}$ 
mekanisme penghambatan pertumbuhan patogen oleh bakteri endofit meliputi: produksi siderofor, antibiosis, ketahanan terinduksi, kompetisi, parasitisme dan produksi enzim ekstraseluler.

Kemampuan Bakteri Endofit Menekan Penyakit Layu Stewart pada Tanaman Jagung. Hasil penelitian menunjukkan bahwa perlakuan bakteri endofit pada benih jagung manis SD3 dengan isolat endofit AN6 dan AJ15 berpengaruh nyata terhadap periode inkubasi penyakit layu stewart. Sementara isolat lainnya menunjukkan kemampuan yang tidak berbeda nyata dengan kontrol. Kedua isolat ini serta AR1, AJ19, AJ14 dan AJ34 berpengaruh nyata terhadap keparahan penyakit layu stewart bila dibandingkan dengan kontrol, dimana persentase keparahan penyakit berkisar 24,42$28,08 \%$ sementara kontrol $55 \%$. Persentase penekanan keparahan penyakit layu stewart oleh enam isolat endofit ini adalah 48,95-55,60\% (Tabel 3). Hal ini menunjukkan bahwa keenam isolat ini dapat menginduksi ketahanan tanaman jagung terhadap infeksi Pnss. Terjadinya penekanan persentase keparahan penyakit layu stewart, mengindikasikan bahwa ke-6 isolat ini memiliki potensi untuk mengendalikan penyakit layu stewart pada tanaman jagung.

Aplikasi bakteri endofit sebagai agens hayati telah dilaporkan oleh beberapa peneliti, diantaranya perlakuan benih Pisum sativum menggunakan bakteri endofit Pseudomonas fluorescens ISR 34 dan Bacillus sp ISR37 mampu menekan persentase kejadian penyakit downy mildew (Sclerospora graminicola) mencapai 53 dan 55\% pada kondisi rumah kaca dan lapang. Perlakuan benih menggunakan bakteri endofit Bacillus pumilus SE34 mampu menurunkan beberapa kejadian penyakit seperti busuk akar oleh Fusarium oxysporum f.sp. pisi pada tanaman Pisum sativum dan meningkatkan ketahanan tanaman tomat terhadap Fusarium oxysporum f.sp. lycopersici (Benhamou et al., 1996). Serratia marcescens strain 90-66 yang mengkolonisasi jaringan akar, mampu menimbulkan induksi ketahanan tanaman mentimun terhadap penyakit layu Fusarium menggunakan metode split-root system (Liu et al., 1995).

Penyakit layu stewart merupakan penyakit tular benih yang baru terdeteksi di Indonesia (Rahma et al., 2013). Keberadaan patogen ini pada benih berpotensi

Tabel 3. Pengaruh perlakuan benih menggunakan bakteri endofit terhadap keparahan penyakit layu stewart pada tanaman jagung manis SD3

\begin{tabular}{lccc}
\hline Bakteri endofit & $\begin{array}{c}\text { Periode Inkubasi } \\
\text { (hsi) }\end{array}$ & $\begin{array}{c}\text { Keparahan penyakit } \\
(\%)\end{array}$ & $\begin{array}{c}\text { Penekanan keparahan } \\
\text { penyakit }(\%)\end{array}$ \\
\hline AN6 & $6,00 \mathrm{a}$ & $24,42 \mathrm{a}$ & $55,60 \mathrm{a}$ \\
AJ15 & $6,00 \mathrm{a}$ & $28,08 \mathrm{a}$ & $48,95 \mathrm{ab}$ \\
AR1 & $4,25 \mathrm{ab}$ & $24,83 \mathrm{a}$ & $54,85 \mathrm{a}$ \\
KB4 & $3,75 \mathrm{ab}$ & $38,67 \mathrm{ab}$ & $29,58 \mathrm{c}$ \\
AJ12 & $3,75 \mathrm{ab}$ & $35,83 \mathrm{ab}$ & $34,85 \mathrm{~b}$ \\
AJ19 & $4,75 \mathrm{ab}$ & $27,83 \mathrm{a}$ & $49,40 \mathrm{ab}$ \\
DK2 & $3,75 \mathrm{ab}$ & $42,17 \mathrm{ab}$ & $23,33 \mathrm{c}$ \\
AJ2 & $5,50 \mathrm{ab}$ & $33,00 \mathrm{ab}$ & $40,00 \mathrm{ab}$ \\
AJ8 & $3,75 \mathrm{ab}$ & $33,17 \mathrm{ab}$ & $39,69 \mathrm{~b}$ \\
AR2 & $4,50 \mathrm{ab}$ & $33,67 \mathrm{ab}$ & $38,78 \mathrm{~b}$ \\
BS7 & $4,50 \mathrm{ab}$ & $33,83 \mathrm{ab}$ & $38,49 \mathrm{~b}$ \\
DK1 & $5,25 \mathrm{ab}$ & $33,83 \mathrm{ab}$ & $38,49 \mathrm{~b}$ \\
BS5 & $3,75 \mathrm{ab}$ & $35,08 \mathrm{ab}$ & $36,22 \mathrm{~b}$ \\
BM4 & $3,75 \mathrm{ab}$ & $35,33 \mathrm{ab}$ & $35,76 \mathrm{~b}$ \\
AJ14 & $3,00 \mathrm{~b}$ & $25,42 \mathrm{a}$ & $53,78 \mathrm{a}$ \\
AJ34 & $3,00 \mathrm{~b}$ & $27,50 \mathrm{a}$ & $50,00 \mathrm{a}$ \\
SS9 & $3,00 \mathrm{~b}$ & $39,83 \mathrm{ab}$ & $27,58 \mathrm{c}$ \\
NK1 & $3,00 \mathrm{~b}$ & $34,33 \mathrm{ab}$ & $37,58 \mathrm{~b}$ \\
Kontrol & $3,00 \mathrm{~b}$ & $55,00 \mathrm{c}$ & 0,00 \\
\hline
\end{tabular}

Angka yang diikuti huruf yang sama pada kolom yang sama menunjukkan tidak berbeda nyata berdasarkan uji DNMRT pada taraf nyata $5 \%$. 
sebagai sumber inokulum di lapang. Oleh karena itu perlakuan benih menggunakan bakteri endofit dapat menjadi salah satu alternatif pengendalian untuk mengurangi kejadian penyakit di lapang serta untuk meningkatkan mutu kesehatan benih.

\section{SIMPULAN}

Hasil isolasi bakteri endofit dari akar jagung, benih jagung, serta akar rumput, didapatkan 17 isolat yang berpotensi sebagai agens hayati: 9 isolat mampu mensintesis IAA, melarutkan fosfat dan menghasilkan siderofor; 2 isolat hanya mampu mensintesis IAA dan melarutkan fosfat dan 6 isolat hanya mampu mensintesis IAA. Perlakuan benih oleh bakteri endofit isolat AN6, AJ15, AR1, AJ19, AJ14 dan AJ34 mampu menginduksi ketahanan tanaman jagung dengan persentase keparahan penyakit layu stewart $24,42-28,08 \%$ dan berbeda nyata dengan kontrol 55,0\%. Persentase penekanan keparahan penyakit layu stewart oleh 6 isolat endofit ini adalah 48,95-55,60\%.

\section{SANWACANA}

Terima kasih kepada Direktorat Jendral Pendidikan Tinggi Kementerian Pendidikan Nasional, atas bantuan biaya penelitian melalui Penelitian Hibah Bersaing Nomor: 005/SP2H/PL/Dit.Litabmas/IV/2011 Tanggal 14 April 2011 dan Nomor: 003/UN.16/PL/MTHB/I/2012 Tanggal 24 Januari 2012.

\section{DAFTAR PUSTAKA}

Awais M, Pervez A, Yaqub A, \& Shah MM. 2010. Production of antimicrobial metabolites by Bacillus subtilis immobilized in polyacrylamide gel. Pakistan J. Zool. 42(3): 267-275.

Barzanti R, Ozino F, Bazzicalupo M, Gabbrielli R, Galardi F, Gonnelli C, \& Mengoni A. 2007. Isolation and characterization of endophytic bacteria from the nickel hyper accumulator plant Alyssum bertolonii. Microb. Ecol. 53(2): 306-316.

Benhamou N, Kloepper JW, Hallmann AQ, \& Tuzun S. 1996. Induction defense related ultrastructural modifications in pea root tissues inoculated with endophytic bacteria. Plant Physiol. 112(3): 919929.
Chanway CP. 1997. Inoculation of tree roots with plant growth promoting soil bacteria: an emerging technology for reforestation. For Sci. 43(1): 99112.

Chen C, Bauske EM, Musson G, Rodriguezkaban R, \& Kloepper JW. 1995. Biological control of fusarium wilt on cotton by use of endophytic bacteria. Biol Cont. 5:83-91.

Fuente DL, Bajsa N, Bagnasco P, Quagliotto L, Thomashow L, \& Arias A. 2004. Antibiotic production by biocontrol Pseudomonas fluorescens isolated from forage legume rhizosphere. http://www.ag.auburn.edu/ argentina/pdfmanuscripts/delafuent.pdf . [1 Februari 2012].

Gravel V, Antoun H, \& Tweddell RJ. 2007. Growth stimulation and fruit yield improvement of greenhouse tomato plants by inoculation with Pseudomonas putida or Trichoderma atroviride : possible role of indole acetic acid (IAA). Soil Biol. Biochem. 39(8): 1968-1977.doi: 10.1016/ j.soilbio.2007.02.015.

Hallmann J. 2001. Plant interaction with endophytic bacteria. In: Jeger MJ \& Spense NJ (Eds.). Biotic Interactions in Plant-Pathogen Association. pp. 87-119. Cab International. Wallingford,UK.

Kuklinsky-Sobral J, WLAraújo, R Mendes IO, Geraldi AA, Pizzirani-Kleiner, \& JL. Azevedo. 2004. Isolation and characterization of soybeanassociated bacteria and their potential for plant growth promotion. Environ. Microbiol. 6 (12):1244-1251.

Liu L, Kloepper JW, \& Tuzun S. 1995. Induction of systemic resistance in cucumber against Fusarium wilt by plant growth-promoting rhizobacteria. Phytopathology 85(6): 695-698

Long HH, Schmidt DD, \& Baldwin IT. 2008. Native Bacterial Endophytes Promote Host Growth in a Species-Specific Manner; Phytohormone Manipulations Do Not Result in Common Growth Responses, PLoS ONE 3(7): e2702.doi:10.1371/ journal.pone.0002702.

Lyon G. 2007. Agents that can elicit induced resistance. In: Walters D, Newton A, \& Lyon G (Eds.). Induced Resistance for plant Defence: Sustainable Approach to Crop Protection. pp. 9-29. Blackwell Publishing, Oxford. 
Madigan MT, Martinko JM, Parker J. 1997. Biology of Microorganisms. 8th ed. Prentice Hall papper Saddle River Press, London.

Pattern CL \& Glick BR. 2002. Role of Pseudomonas putida indoleacetic acid in development of the host plant rootsystem. Appl. Environ. Microbiol. 68: 3795-3801.

Rahma H \& Armansyah. 2008. Deteksi Penyakit Stewart oleh Bakteri Pantoea stewartii subsp. stewartii sebagai Penyakit Baru pada Tanaman Jagung (Zea mays): Studi Kasus di Pasaman Barat. J. Manggaro. 9(2): 1-5.

Rahma H. 2013. Penyakit Layu Stewart (Pantoea stewartii subsp. stewartii) pada Jagung dan Upaya Pengendaliannya. [Disertasi]. Bogor. Institut Pertanian Bogor.

Rahma H, Sinaga MS, Surahman M, \& Giyanto. 2013. Tingkat Kejadian Penyakit Layu Stewart pada Benih dan Respon beberapa Varietas Jagung terhadap Infeksi Pantoea stewartii subsp. stewartii. J. HPT. Tropika. 13(1): 1-9.

Rao WVBS \& Sinha MK. 1962. Phosphate dissolving microorganism in the soil and rhizosphere. Indian J. Sci. 23: 272-278.

Rao NSS. 1994. Mikroorganisme Tanah dan Pertumbuhan Tanaman. Edisi ke dua. Terjemahan Herawati Susilo. UI Press. Jakarta.
Rijavec T, Lapanje A, Dermastia M, \& Rupnik M. 2007 Isolation of bacterial endophytes from germinated maize kernels. Can. J. Microbiol. 53(6): 802 808.

Rodríguez H \& Fraga R. 1999. Phosphate solubilizing bacteria and their role in plant growth promotion. Biotech Adv. 17(4-5): 319-339.

Sessitsch A, Reiter B, \& Berg G. 2004. Endophytic bacterial communities of field-grown potato plants and their plant-growth-promoting and antagonistic abilities. Can J Microbiol. 50(4): 239-249.

Sigee DC. 1993. Bacterial plant pathology. Cambridge. University Press.

Unterstenhöfer, G. 1963. The basic principles of crop protection field trials. Pflanzenschutz-Nachrichten 16(3): 155-156.

Velusamy P, Immanuel JE, Gnanamanickam SS, \& Thomashow L. 2006. Biological control of rice bacterial blight by plant associated bacteria producing 2,4 diacetylphloroglucinol. Can J. Microbiol. 52(1): 56-65.

Whipps JM. 2001. Microbial interactions and biocontrol in the rhizosphere. J. Exp. Bot. 52(11): 487-511.

Zinniel DK, Lambrecht P, Harris NB, Feng Z, Kuczmarski, Higley P, Ishimaru CA, Arunakumari A, Barletta RG, \& Vidaver AK. 2002. Isolation and characterization of endophytic colonizing bacteria from agronomic crop and prairie plants. Appl. Environ. Microbiol. 68(5): 2198-2208. 